\title{
Instantaneous Perturbation of Dentate Interneuronal Networks by a Pressure Wave-Transient Delivered to the Neocortex
}

\author{
Zsolt Toth, Greg S. Hollrigel, Tamas Gorcs, and Ivan Soltesz \\ Department of Anatomy and Neurobiology, University of California, Irvine, California 92697
}

\begin{abstract}
Whole-cell patch-clamp recordings and immunocytochemical experiments were performed to determine the short- and longterm effects of lateral fluid percussion head injury on the perisomatic inhibitory control of dentate granule cells in the adult rat, with special reference to the development of traumainduced hyperexcitability. One week after the delivery of a single, moderate (2.0-2.2 atm) mechanical pressure wave to the neocortex, the feed-forward inhibitory control of dentate granule cell discharges was compromised, and the frequency of miniature IPSCs was decreased. Consistent with the electrophysiological data, the number of hilar parvalbumin (PV)- and cholecystokinin (CCK)-positive dentate interneurons supplying the inhibitory innervation of the perisomatic region of granule cells was decreased weeks and months after head injury. The initial injury to the hilar neurons took place instantaneously after
\end{abstract}

the impact and did not require the recruitment of active physiological processes. Furthermore, the decrease in the number of PV- and CCK-positive hilar interneurons was similar to the decrease in the number of the AMPA-type glutamate receptor subunit 2/3-immunoreactive mossy cells, indicating that the pressure wave-transient causes injurious physical stretching and bending of most cells that are large and not tightly packed in a cell layer.

These results reveal for the first time that moderate pressure wave-transients, triggered by traumatic head injury episodes, impact the dentate neuronal network in a unique temporal and spatial pattern, resulting in a net decrease in the perisomatic control of granule cell discharges.

Key words: interneuron; GABA; epilepsy; trauma; parvalbumin; cholecystokinin
Postmortem examinations of head-injured patients often reveal selective damage to the hippocampus, frequently restricted to the dentate hilus ("end-folium sclerosis") (Margerison and Corsellis, 1966; Bruton, 1988). Hilar cells play a central role in the regulation of the input-output functions of the dentate gyrus (Amaral, 1978; Buzsáki et al., 1983), and the post-traumatic loss of these neurons is thought to be an important factor in the development of trauma-induced epilepsy, a disorder that affects a large percentage of head-injured patients (Annegers et al., 1980; Salazar et al., 1985). However, little is known about the precise nature of the functional defects that underlie trauma-induced hyperexcitability in the limbic system.

The discharges of dentate granule cells are regulated by at least five types of GABAergic interneurons (Halasy and Somogyi, 1993; Han et al., 1993). These distinct classes of GABAergic cells supply inhibitory innervation to spatially segregated parts of the granule cells, including the axon initial segment, soma, and proximal and distal dendrites. Basket and axo-axonic cells in the dentate gyrus play a central role in controlling the entorhinohippocampal interplay because these cells are activated by the perforant path in a feed-forward manner, and they evoke powerful inhibitory postsynaptic events by GABA released from their

Received July 8, 1997; revised Aug. 8, 1997; accepted Aug. 11, 1997.

This work was supported by National Institutes of Health (1R29NS35916-01A1) and the American Epilepsy Society (EFA-21311) to I.S. We thank Dr. K. G. Baimbridge for the generous gift of the anti-parvalbumin antibody, Dr. R. Shigemoto for the anti-substance P receptor antibody, Dr. L. Acsády and Dr. B. Lyeth for advice, Ms. G. Sándor and Ms. M. He for expert technical assistance, Dr. J. Dempster for providing the Strathclyde Electrophysiology Software, and Dr. Y. De Koninck for the Synapse software.

Z.T. and G.S.H. contributed equally to this paper.

Correspondence should be addressed to Dr. Ivan Soltesz, Department of Anatomy and Neurobiology, University of California, Irvine, CA 92697-1280.

Copyright (C) 1997 Society for Neuroscience $0270-6474 / 97 / 178106-12 \$ 05.00 / 0$ terminals located proximal to the action potential initiation site on granule cells (Halasy and Somogyi, 1993; Han et al., 1993). Given the strategic location of the dentate gyrus in the limbic system, post-traumatic perturbation of the feed-forward, perisomatic inhibitory control of granule cell discharges is likely to be crucially important in the development of head injury-induced epilepsies.

This study was undertaken to test the hypothesis that moderate traumatic head injury leads to a severe disturbance of the feedforward, perisomatic, $\mathrm{GABA}_{\mathrm{A}}$ receptor-mediated inhibition of dentate granule cells. To achieve this aim, the fluid percussion model of head trauma was used (Dixon et al., 1989; McIntosh et al., 1989), which involves the unilateral delivery of a single, brief $(20 \mathrm{msec})$ pressure wave-transient to the exposed dura. At mild to moderate impact forces, there is minimal cortical injury, similar to that which occurs in humans after mild to moderate closed head injury. Fluid percussion injury leads to neurological and behavioral features similar to mild to moderate head injury in humans, including hyperexcitability and memory and motor deficits (Lyeth et al., 1988; Dixon et al., 1989; Lowenstein et al., 1992). Specifically, we sought to answer the following questions. (1) Is the feed-forward inhibitory control of granule cell discharges decreased after head injury? (2) Is there a post-traumatic decrease in the frequency of the miniature IPSCs (mIPSCs), indicating a perturbation of the perisomatic inhibitory synapses? (3) Is there a change in the amplitude and kinetics of mIPSCs after head injury? (4) Are there morphological correlates of damage to the basket and axo-axonic interneuronal populations in the dentate gyrus? (5) How fast does the injury from the pressure transient take place after the impact? The answers to these questions are important because they advance our knowledge of how perturbed hippocampal GABAergic inhibition de- 
velops and contributes to the hyperexcitable state of the posttraumatic corticolimbic system.

\section{MATERIALS AND METHODS}

Lateral fluid percussion injury. The lateral fluid percussion technique was performed as described previously (Dixon et al., 1989; McIntosh et al., 1989; Lowenstein et al., 1992). Briefly, adult (200 gm) male Wistar rats were anesthetized with Nembutal $(65 \mathrm{mg} / \mathrm{kg}$, i.p.; adequate anesthesia was ascertained repeatedly by the lack of the ocular reflex and the absence of withdrawal response to a pinch of the hindlimb) and placed in a stereotaxic frame, and the scalp was sagittally incised. A $2 \mathrm{~mm}$ hole was trephined to the skull at $-3 \mathrm{~mm}$ from bregma, $3.5 \mathrm{~mm}$ lateral from the sagittal suture. Two steel screws were placed $1 \mathrm{~mm}$ rostral to bregma and $1 \mathrm{~mm}$ caudal to lambda. A Luer-Loc syringe hub with a $2.6 \mathrm{~mm}$ inside diameter was placed over the exposed dura and bonded to the skull with cyanoacrylate adhesive. Dental acrylic was poured around the injury tube and skull screws and allowed to harden, and the scalp was sutured. Bacitracin was applied to the wound, and the animal was returned to its home cage. One day later, the rats were anesthetized with halothane in a 21 chamber. After the animal was anesthetized (surgical level of anesthesia was ascertained as described above), it was removed from the anesthetizing chamber and immediately connected to the injury device (see below). The establishment of the connection to the device took 5 $\mathrm{sec}$, and the actual injury (release of the pendulum) took another $5 \mathrm{sec}$; therefore, the animal was fully anesthetized at the time of injury, although the halothane anesthesia was not actively administered at that time. All animals were immediately ventilated with room air. The animals were injured either by a mild (1.4-1.6 atm) or, in most cases, a moderate $(2.0-2.2 \mathrm{~atm})$ impact. These mild and moderate levels of injury were selected to produce neuronal degeneration in the dentate gyrus similar to those reported previously (Lowenstein et al., 1992). Agematched, sham-operated control animals were treated the same way, including the connection to the fluid percussion injury device, but the pendulum (see below) was not released. The animals recovered fully from anesthesia within 10-15 min, and their subsequent behaviors, such as feeding and grooming, were normal. After survival periods of 1 week or 1-8 month(s), the animals were euthanized after deep Nembutal anesthesia either by decapitation for slice physiology or by transcardial perfusion of fixative for morphological studies (see below).

The fluid percussion device (Department of Biomedical Engineering, Virginia Commonwealth University, Richmond, Virginia) was identical to that used by several other laboratories (Cortez et al., 1989; Dixon et al., 1989; McIntosh et al., 1989; Lowenstein et al., 1992; Povlishok et al., 1994; Prasad et al., 1994; Coulter et al., 1996). Briefly, the device consisted of a Plexiglas cylinder reservoir $60 \mathrm{~cm}$ long and $4.5 \mathrm{~cm}$ in diameter. At one end of the cylinder a rubber-covered Plexiglas piston was mounted on $\mathrm{O}$ rings. The opposite end of the cylinder had an $8 \mathrm{~cm}$ long metal housing that contained a transducer. Fitted at the end of the metal housing was a $5 \mathrm{~mm}$ tube with a $2 \mathrm{~mm}$ inner diameter that terminated in a male Luer-Loc fitting. This fitting was then connected to the female fitting that had been chronically implanted. The entire system was filled with saline. The injury was produced by a metal pendulum that strikes the piston of the injury device. The resulting pressure pulse was recorded extracranially by a transducer and expressed in atmospheres pressure. This injury device injected a small volume of saline into the closed cranial cavity and produced a brief $(20 \mathrm{msec})$ displacement and deformation of brain tissue. The magnitude of injury was controlled by varying the height from which the pendulum was released (in these experiments, it was $10-13.5^{\circ}$, which produced $1.4-2.2$ atm pressure waves). It has been shown that the monitoring of blood pressures and arterial blood gases during and after fluid percussion injury showed no evidence of significant cardiorespiratory compromise in the injured animals (Lowenstein et al., 1992). The delivery of the pressure pulse was associated with brief $(<120-200 \mathrm{sec})$, transient traumatic unconsciousness (as assessed by the duration of the suppression of the righting reflex). Although the injured animals in this study, subjected only to mild or moderate impacts, did not exhibit any obvious lasting behavioral deficit or seizure activity, fluid percussion head injury, especially at higher impact forces, can lead to detectable motor and memory deficits that last for days (Lyeth et al., 1988; McIntosh et al., 1989; Povlishock et al., 1994). Before and during each experiment, great care was taken to ensure that no air bubble was trapped or had formed in the device. Furthermore, in each experiment the pressure wave was closely examined on the oscilloscope for any sign of a jagged rising edge (which would indicate the presence of air bubbles in the system), and the amplitude of the oscilloscope reading of the pressure wave was recorded.

Slice preparation. Brain slices were prepared as described previously (Otis and Mody, 1992; Staley et al., 1992; Soltesz and Mody, 1994). The fluid percussion-injured and the sham-operated, age-matched rats were anesthetized with sodium pentobarbital ( $75 \mathrm{mg} / \mathrm{kg}$, i.p.). Anesthetized rats were decapitated, and the brains were removed and cooled in $4^{\circ} \mathrm{C}$ oxygenated $\left(95 \% \mathrm{O}_{2} / 5 \% \mathrm{CO}_{2}\right)$ artificial cerebral spinal fluid (ACSF) composed of (in mM): $126 \mathrm{NaCl}, 2.5 \mathrm{KCl}, 26 \mathrm{NaHCO}_{3}, 2 \mathrm{CaCl}_{2}, 2$ $\mathrm{MgCl}_{2}, 1.25 \mathrm{NaH}_{2} \mathrm{PO}_{4}$, and 10 glucose. Horizontal brain slices (Staley et al., 1992) $(450 \mu \mathrm{m})$ were prepared with a vibratome tissue sectioner (Lancer Series 1000) from the midsection of the hippocampus (see text for rationale and details). This procedure yielded approximately six slices. The brain slices were sagittally bisected into two hemispheric components, and the ipsilateral slices were incubated submerged in $32^{\circ} \mathrm{C}$ ACSF for $1 \mathrm{hr}$ in a holding chamber (the contralateral slices were not examined during the physiological experiments). Two ipsilateral slices from each animal were transferred to fixative and later resectioned at 30 $\mu \mathrm{m}$ and stained for Nissl substance.

Electrophysiology. Individual slices were transferred to a recording chamber (Soltesz et al., 1995; Hollrigel et al., 1996, 1997) perfused with ACSF with or without bicuculline methiodide (BMI) (for the field recording experiments) or with ACSF containing $10 \mu \mathrm{M}$ 2-amino-5phosphovaleric acid (APV), $5 \mu \mathrm{M}$ 6-cyano-7-nitroquinoxaline-2,3-dione (CNQX), and $1 \mu \mathrm{M}$ tetrodotoxin (TTX) (for the whole-cell patch-clamp experiments). The brain slices rested on filter paper and were stabilized with platinum wire weights. The tissue was continuously superfused with humidified $95 \% \mathrm{O}_{2} / 5 \% \mathrm{CO}_{2}$, and the temperature of the perfusion solution was maintained at $36^{\circ} \mathrm{C}$. All salts were obtained from Fluka (Buchs, Switzerland). APV and CNQX were purchased from Tocris, BMI from Research Biochemicals International (Natick, MA), and TTX from Calbiochem (La Jolla, CA).

Patch pipettes were pulled from borosilicate (KG-33) glass capillary tubing (1.5 mm outer diameter; Garner Glass) with a Narishige PP-83 two-stage electrode puller. Pipette solutions consisted of (in mM): 140 $\mathrm{CsCl}, 2 \mathrm{MgCl}_{2}$, and $10 \mathrm{HEPES}$. "Blind" whole-cell recordings were obtained as described previously (Blanton et al., 1989; Staley et al., 1992). Recordings were obtained with an Axopatch-200A amplifier (Axon Instruments, Foster City, CA) and digitized at $88 \mathrm{kHz}$ (Neurocorder, NeuroData) before being stored in pulse code modulation form on videotape. The series resistance was monitored throughout the recordings, and the data were rejected if they increased beyond $15 \mathrm{M} \Omega$. Field recordings of orthodromic population spikes in the granule cell layer of the dentate gyrus were conducted using patch pipettes filled with ACSF. To evoke the field responses, constant-current stimuli $(10 \mu \mathrm{A}$ to $10 \mathrm{~mA}$; $50-200 \mu \mathrm{sec}$ ) were applied at $0.1 \mathrm{~Hz}$ through a bipolar $90 \mu \mathrm{m}$ tungstenstimulating electrode placed in the perforant path, just outside the molecular layer at the junction of the dorsal blade and the crest. The field responses in the granule cell layer were measured at five predetermined points in each slice, including the tips of the dorsal and the ventral blades, the middle of the dorsal and ventral blades, and the middle of the crest, and the largest response was studied further.

Analysis. Recordings of mIPSCs were filtered at $3 \mathrm{kHz}$ before digitization at $20 \mathrm{kHz}$ by a personal computer for analysis, using Strathclyde Electrophysiology Software (courtesy of Dr. J. Dempster, University of Strathclyde) and Synapse software (courtesy of Dr. Y. De Koninck, McGill University). Detection of individual mIPSCs was performed with a software trigger described previously (Otis and Mody, 1992; Soltesz et al., 1995). All of the detected events were analyzed, and any noise that spuriously met trigger specifications was rejected. A least-squares Simplex-based algorithm was used to fit the ensemble average with the sum of two (one rising and one decaying) exponentials:

$$
I(t)=-A * e^{-\tau_{r / t}}+A * e^{-\tau_{D / t}}
$$

where $I(t)$ is the mIPSC as a function of time $(t)$, A is a constant, and $\tau_{\mathrm{r}}$ and $\tau_{\mathrm{D}}$ are the rise and decay time constants, respectively. As described before (Otis and Mody, 1992; Soltesz and Mody, 1995), the decay of mIPSCs in adult granule cells can be described satisfactorily by a single exponential. Statistical analyses were performed with SPSS for Windows or SigmaPlot, with a level of significance of $p \leq 0.05$. Data are presented as mean $\pm \mathrm{SE}$.

Histology. For the histological and immunocytochemical experiments, the animals were perfused transcardially with a fixative containing either $4 \%$ paraformaldehyde and $15 \%$ picric acid [for parvalbumin (PV) and substance P receptor (SPR) immunocytochemistry] or 5\% acrolein [for 
cholecystokinin (CCK) and glutamate receptor subunit 2/3 (GluR2/3) immunocytochemistry]. The brain was removed and hemisected, and the ipsilateral hippocampus was dissected and put into fixative for an additional $2 \mathrm{~d}$. Next, the hippocampus was straightened out and placed in a gelatin-based supporting block, and transverse 30- $\mu \mathrm{m}$-thick sections were cut on a vibratome. Every 20th section (i.e., at every $600 \mu \mathrm{m}$ ) was collected in the wells of a tissue culture plate for immunocytochemistry, preserving the serial order of the sections, and in a separate tissue culture plate, every 21 st section was collected for Nissl staining. In each immunocytochemical staining session, at least one fluid percussion-injured and one age-matched, sham-operated control rat were used, and the sections from the injured and the control rats were processed at the same time in the same wells. Sections from the injured and control animals were labeled by zero to three small cuts with the scalpel blade across the subicular region. This was necessary so that we could process four sections in a single well; on the basis of the number of small cuts, the sections could be separated later (the main advantage of this method is that the sections are processed in the same well, ruling out systematic differences between the treatment of the control and the fluid percussioninjured sections). The first and last two sections (i.e., $\sim 1.2 \mathrm{~mm}$ from the ventral and dorsal tips) could not be used for quantitative counting of immunostained dentate neurons or Nissl-stained hilar cells because the granule cell layer and the hilus in these sections became difficult to delineate precisely. Therefore, with this method we could not examine the most dorsal and ventral tip of the hippocampus, and consequently we could not calculate with full confidence the total hilar cell loss for the whole hippocampus; however, this restriction is of no consequence for the experiments (see below).

The sections were washed in $0.1 \mathrm{~m}$ phosphate buffer, $\mathrm{pH} 7.4$, and processed for Nissl staining or immunocytochemistry. For immunocytochemistry, sections were incubated in 10\% normal goat serum (NGS; 45 $\mathrm{min})$ and then in primary antisera against (1) PV (1:2000; courtesy of Dr. K. G. Baimbridge) (Baimbridge and Miller, 1982), (2) SPR (1:1000; courtesy of Dr. R. Shigemoto) (Shigemoto et al., 1993; Acsády et al., 1997), (3) CCK (1:5000) (Gulyás et al., 1990), or (4) GluR2/3 (1:1000; Chemicon, Temecula, CA) (Leranth et al., 1996) for 1 (for PV) or $2 \mathrm{~d}$ (for SPR, CCK, and GluR2/3), followed by incubation in goat-anti-rabbit IgG (for PV, 1:100; for SPR, 1:200; for CCK and GluR2/3, 1:300; ICN Biochemicals, Costa Mesa, CA) for $6 \mathrm{hr}$, and then in peroxidase antiperoxidase complex (1:100, Dakopatts, Copenhagen, Denmark) overnight. The sections were washed $3 \times 30 \mathrm{~min}$ between each serum. All washing steps and dilution of antisera were performed in $50 \mathrm{~mm}$ Tris-buffered saline, $\mathrm{pH} 7.4$, containing $1 \%$ NGS $+0.5 \%$ Triton X-100.

After the immunocytochemical experiments, the sections were taken from the wells and separated into ipsilateral, contralateral, fluid percussion-injured, and control categories using the dissecting microscope. The sections were then mounted on gelatin-coated slides, dried, dehydrated, and covered with neutral medium and a coverslip. Next, the immunoreactive cell bodies in the hilus, granule cell layer, and molecular layer or the Nissl-stained hilar cells from each section were drawn using a camera lucida and counted [stained somata that came into focus while the counting investigator focused down through the slice (the dissector height) were counted (West et al., 1991); dissector height was the section thickness, and the total area under scrutiny (e.g., the hilus, the granule cell, or molecular layers) was counted (Buckmaster et al., 1996)]. The hilus was defined as the area between the granule cell layer and the two lines connecting the two tips of the granule cell layer to the tip of the $\mathrm{CA} 3 \mathrm{c}$ region. In the case of those cells that were situated at the border of the hilus and the granule cell layer, the cells were classified as hilar cells if more than half of their cell bodies were in the hilus.

For the silver stain, the procedure was similar to that described earlier (Gallyas et al., 1990, 1992a,b,c; van den Pol and Gallyas, 1990). Briefly, the animals were anesthetized with sodium pentobarbital and perfused with a fixative containing $4 \%$ paraformaldehyde and $2.5 \%$ glutaraldehyde. The brains were left in the skull overnight (Gallyas et al., 1990; van den Pol and Gallyas, 1990), and the following day they were removed and post-fixed in the same fixative as described above. Sections were cut with a vibratome and placed in 50\%, 75\%, and 100\% 1-propanol for $5 \mathrm{~min}$ each, and then in 1-propanol containing $0.8 \%$ sulfuric acid for $16 \mathrm{hr}$ at $56^{\circ} \mathrm{C}$. The sections were then rehydrated in $50 \%$ and $25 \%$ 1-propanol, washed in distilled water, and treated with $3 \%$ acetic acid for 5 min. Subsequently, the sections were placed in a silicotungstate physical developer (for the composition and preparation of the developer, see Gallyas et al., 1990; van den Pol and Gallyas, 1990) for 10 min, dehydrated, mounted on slides, and coverslipped.

\section{RESULTS}

\section{Hilar cell loss after head injury}

Lateral fluid percussion injury leads to a loss of neurons from the hilus of the dentate gyrus (Lowenstein et al., 1992). In our system, moderate $(2.0-2.2 \mathrm{~atm})$ impact caused a $58.7 \pm 1.8 \%$ cell loss (as determined by cell counts from Nissl-stained sections; see Materials and Methods) in the hilus of the dentate gyrus 1 month after injury, with respect to age-matched, sham-operated controls (mild impact with 1.4-1.6 atm led to a $44.7 \pm 9.8 \%$ decrease, $n=3$; there was no difference between the decrease in the hilar cell numbers 1 week and 1 month after moderate impact). As noted by Schumate et al. (1995), the ventral tip of the hippocampus exhibited a larger cell loss compared with the dorsal end; however, the middle $4.2 \mathrm{~mm}$ of the hippocampus displayed no significant variability in the degree of hilar cell loss along the septotemporal axis. Therefore, the immunocytochemical and electrophysiological data presented in this paper were obtained from the sections/slices originating from the same midsection of the ipsilateral hippocampus. For each animal used for either the immunocytochemical or the electrophysiological experiments, the degree of hilar cell loss was determined, and if it differed significantly from the value presented above, the data obtained from those animals were rejected $(n=2)$.

\section{Decreased feed-forward inhibition of dentate granule cells 1 week after fluid percussion head injury}

The discharge of dentate granule cells is under tight inhibitory control by GABAergic interneurons (Buzsáki et al., 1983; Halasy and Somogyi, 1993; Han et al., 1993; Soltesz et al., 1995). As described earlier, the population EPSPs evoked by single-shock stimulation of the entorhinal fibers in our slices in most cases does not lead to a population discharge, because of the prominent feed-forward activation of $\mathrm{GABA}_{\mathrm{A}}$ receptor-mediated inhibition (Hollrigel et al., 1996). Similarly, in slices obtained from shamoperated, age-matched control animals $(n=3)$, the amplitude of the population spike was small (Fig. $1 A$ ). In fact, in $66 \%$ of the slices, stimulation of the perforant path did not evoke a detectable population spike, even at intensities supramaximal for the population EPSPs. However, population spikes were readily observable in the same control slices when the $\mathrm{GABA}_{\mathrm{A}}$ receptor antagonist bicuculline $(20 \mu \mathrm{M})$ was included in the perfusate (Fig. $1 B)$, indicating that strong feed-forward $\mathrm{GABA}_{\mathrm{A}}$ inhibition is responsible for the lack of a population discharge after activation of the perforant fiber afferents in control slices. In contrast to the small amplitude of the population spikes in control slices in control medium (i.e., without bicuculline), the amplitude of the population spike in slices from fluid percussion-injured animals $(n=4)$ was significantly higher 1 week after impact (Fig. 1C) (also, in $83 \%$ of the slices from fluid percussion-injured animals, population discharges could be readily observed). The amplitude of the population EPSPs in response to low intensity stimulation (i.e., without the presence of population spikes, which would make exact comparison of the field EPSPs between control and injured slices difficult) was not different (control: $1.18 \pm 0.2 \mathrm{mV}$; fluid percussion injured: $0.88 \pm 0.2 \mathrm{mV}$ ). These field-response data indicate that head trauma leads to a prominent decrease in feed-forward $\mathrm{GABA}_{\mathrm{A}}$ receptor-mediated inhibition of granule cell discharges.

\section{Decreased frequency of miniature IPSCs in granule cells 1 week after injury}

Basket and axo-axonic cells are important in generating feedforward inhibition in the hippocampal formation (Buzsáki et al., 


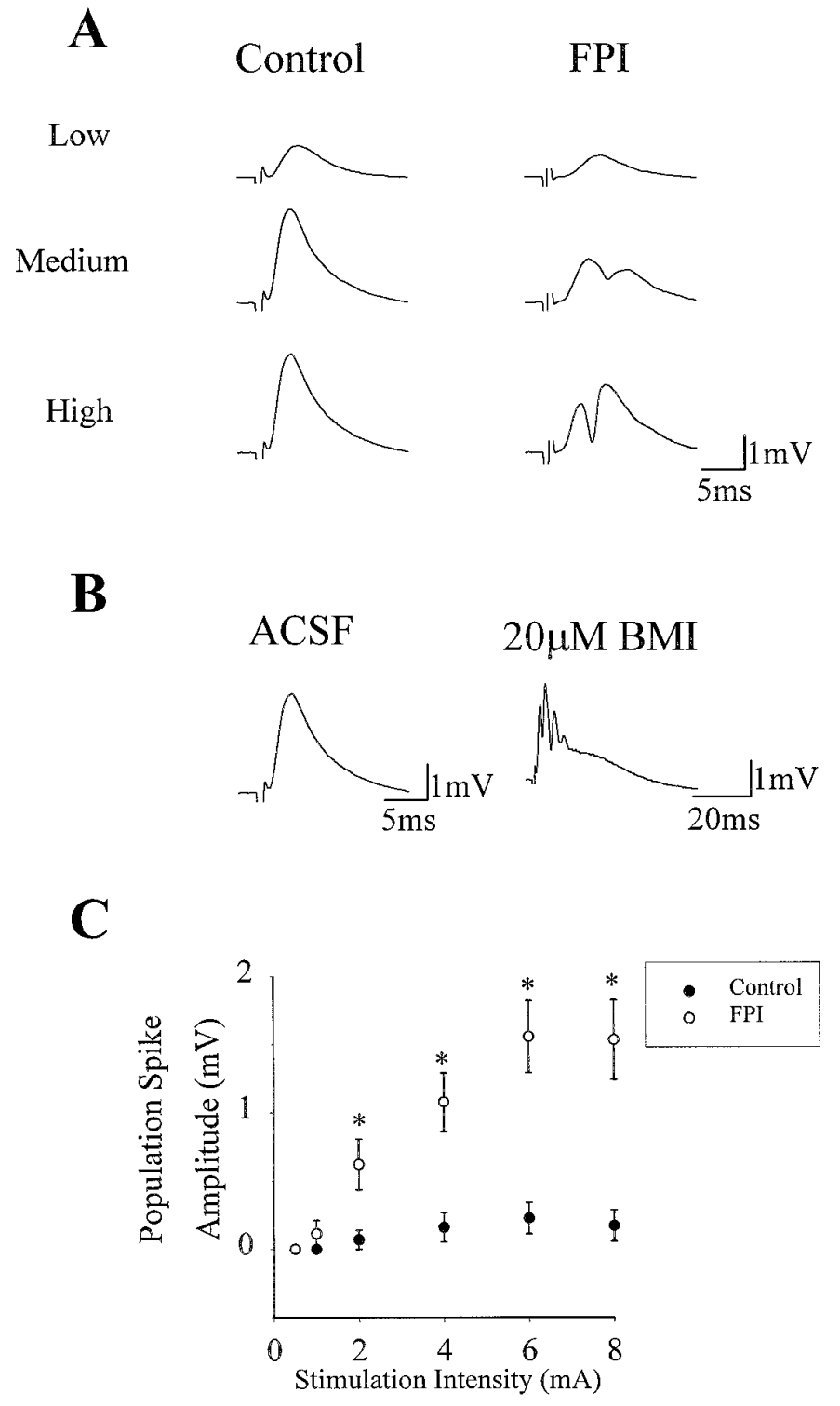

Figure 1. Decreased feed-forward inhibition of dentate granule cells 1 week after fluid percussion head injury. $A$, Field recordings of perforant path-evoked granule cell responses 1 week after moderate head injury in slices obtained from a fluid percussion-injured (FPI) and an age-matched, sham-operated control animal, at three intensities of stimulation (low, 500 $\mu \mathrm{A}$; medium, $2 \mathrm{~mA}$; high, $6 \mathrm{~mA}$ ). The responses recorded in the slice from the fluid percussion-injured animal show population discharge, indicating a decreased ability of the interneuronal network to control the feed-forward activation of granule cells. Note that the EPSPs at lower intensities of stimulation were not statistically different. $B$, In the presence of the $\mathrm{GABA}_{\mathrm{A}}$ receptor antagonist bicuculline $(B M I)$, population spikes can be observed in control slices, indicating that the absence of population spikes in control ACSF in control slices is attributable to the powerful feed-forward activation of interneurons inhibiting granule cell discharges via $\mathrm{GABA}_{\mathrm{A}}$ receptors. $C$, Summary of data obtained in control medium (as shown in $A$ ). Note that the amplitude of the population spike in the slices from fluid percussion-injured animals was larger than in control.

1983; Traub and Miles, 1991; Halasy and Somogyi, 1993; Buhl et al., 1994, 1995; Buckmaster and Schwartzkroin, 1995; Soltesz, 1995; Miles et al., 1996). To determine whether the severe decrease in the ability of the feed-forward inhibitory system to control granule cell discharges is related to a functional decrease in perisomatic inhibition, whole-cell patch-clamp recordings of

A

Control
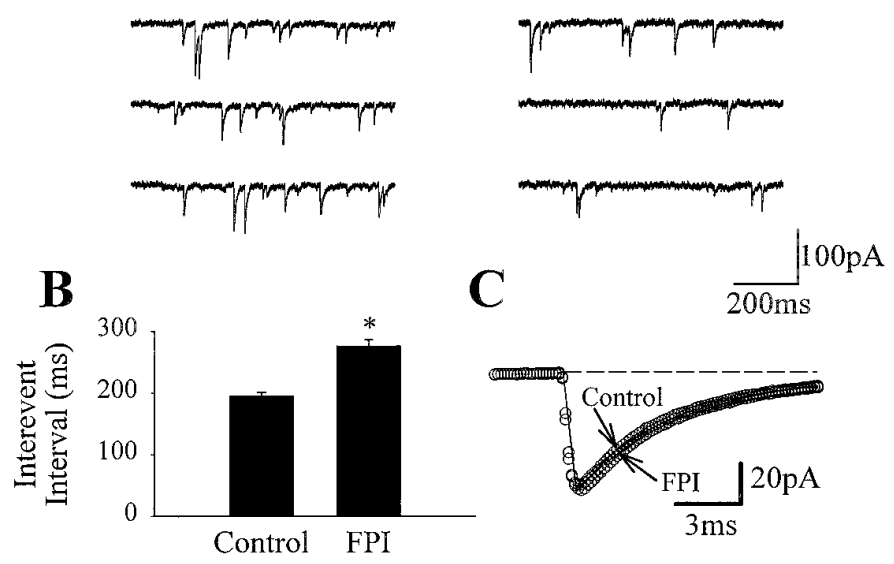

Figure 2. Decreased frequency of mIPSCs in dentate granule cells after head injury. $A$, The traces are representative recordings of mIPSCs (at $-60 \mathrm{mV}$ with $\mathrm{Cl}^{-}$-filled patch pipettes) from dentate granule cells of age-matched, sham-operated control and fluid percussion-injured (FPI) animals, 1 week after injury. $B$, The bar graphs indicate a significantly increased inter-event interval (a decreased frequency) of the mIPSCs from the injured animals. $C$, The figure shows an example of average mIPSCs recorded from granule cells of control and fluid percussioninjured animals; the average currents $(\bigcirc)$ showed complete overlap. The currents were accurately described $(---)$ by the sum of a single exponential rise and a single exponential decay. The amplitude and kinetics of the mIPSCs were not significantly different after fluid percussion injury (for the numerical values of the amplitude and kinetics data, see text).

mIPSCs were performed in control and fluid percussion-injured animals. In dentate granule cells, the mIPSCs originate from synapses close to the soma (Soltesz et al., 1995), i.e., from the target region of the basket and axo-axonic cells. Therefore, a post-traumatic change in the frequency of mIPSCs would indicate a perturbation of the perisomatic inhibitory processes. Whole-cell patch-clamp recordings were performed on dentate granule cells from slices obtained from fluid percussion-injured and age-matched, sham-operated controls, with $\mathrm{Cl}^{-}$-filled patch pipettes $\left(\mathrm{E}_{\mathrm{Cl}}=0 \mathrm{mV}\right)$ at $-60 \mathrm{mV}$, in voltage-clamp configuration (possible post-traumatic changes in the relationship between $\mathrm{E}_{\mathrm{Cl}}$, the resting membrane potential, and neuronal rhythms will be examined in a separate study). As shown in Figure $2 A, B$, there was an increase in the inter-event interval (i.e., a decrease in frequency) of mIPSCs from dentate granule cells in slices from fluid percussion-injured animals compared with age-matched, sham-operated controls (mIPSC inter-event interval, 1 week after injury: $276.84 \pm 5.43 \mathrm{msec}, n=18$, range, $35.74-690.27 \mathrm{msec}$; control: $195.62 \pm 5.43 \mathrm{msec}, n=17$, range, $66.84-391.87 \mathrm{msec}$ ). However, we found no change in the amplitude (control: $56.9 \pm$ $2.8 \mathrm{pA}$; fluid percussion injured: $58.0 \pm 3.1 \mathrm{pA}$ ), rise time (control: $0.22 \pm 0.01 \mathrm{msec}$; fluid percussion injured: $0.26 \pm 0.02 \mathrm{msec}$ ) or decay time constants (control: $4.50 \pm 0.15 \mathrm{msec}$; fluid percussion injured: $4.67 \pm 0.17 \mathrm{msec}$; mIPSCs from both control and injured animals could be satisfactorily fitted by the sum of a single exponential rise and single exponential decay) (Soltesz and Mody, 1995) of the mIPSCs recorded from granule cells in slices from control and fluid percussion-injured animals (Fig. 2C). Taken together, these electrophysiological data indicate a functional disturbance of the feed-forward, perisomatic GABAergic inhibition after head trauma, without a significant postsynaptic change in the amplitude and kinetic properties of $\mathrm{GABA}_{\mathrm{A}}$ receptor-mediated synaptic events. 


\section{Decreased number of PV- and CCK-immunoreactive hilar cells 1 week after fluid percussion injury}

The perisomatic inhibitory control of dentate granule cells is provided by the nonoverlapping populations of $\mathrm{PV}$ - or CCKimmunoreactive interneurons (i.e., basket and axo-axonic cells) (Soriano et al., 1990; Freund and Buzsáki, 1996). Immunocytochemical experiments determined that there was a $67.1 \pm 4.6 \%$ reduction in the number of $\mathrm{PV}$-immunoreactive hilar cells in the ipsilateral dentate gyrus 1 week after fluid percussion injury (Figs. 3 , 4) $(n=6)$. By contrast, the number of PV-positive cells in the ipsilateral granule cell layer was not decreased $(115.3 \pm 10.6 \%$ of control); also, there was no significant decrease in the number of the relatively few PV-positive cells that can be found in the molecular layer (Fig. 4A). In addition to the decrease in the number of $\mathrm{PV}$-immunoreactive hilar cells, there was a prominent reduction in the density of PV-positive axonal processes in and immediately adjacent to the granule cell layer (Fig. 3). Similar to the PV-positive basket and axo-axonic cells, the number of the numerically less significant CCK-positive interneuronal population (Leranth and Frotscher, 1986; Freund and Buzsáki, 1996) was decreased by $55.7 \pm 5.6 \%$ in the hilus (Fig. $4 B)(n=3$ animals) with respect to age-matched, sham-operated controls 1 week after impact, without a change in the number of those CCK-positive basket cells that were located in the granule cell layer (115.4 $\pm 16.9 \%$ of control).

These immunocytochemical observations regarding the decrease in the number of PV- and CCK-immunoreactive cells in the dentate hilus 1 week after head trauma provided the morphological correlates of the field and patch-clamp data indicating the disturbance of perisomatic, feed-forward inhibitory functions in the dentate gyrus after head injury, and they also suggested that the basket and axo-axonic cell populations in the hilus and the granule cell layer may be differentially affected by traumatic head injury. The lack of a post-traumatic decrease in the number of PV- and CCK-positive cells in the granule cell layer, together with the fact that there was no obvious change in the immunoreactivity of those PV- and CCK-positive cell populations that resided in the CA1 or subicular regions, indicated that the decreased number of PV-and CCK-positive cells in the dentate hilus is not related to a general loss of immunoreactivity from the fluid percussion-injured tissue. Furthermore, we found no additional change (decrease or a reversal of the decrease) in the number of PV-immunoreactive hilar cells 1 month versus 1 week after injury ( 1 week: $67.1 \pm 4.6 \%$ decrease; 1 month: $73.7 \pm 6.1 \%$ decrease; $n=3$ animals). In fact, no reversal of the decrease in the number of hilar PV-positive cells could be detected even 8 months after injury in a pair of fluid percussion-injured and age-matched control animals, which showed a $74.2 \%$ decrease in the number of PV-immunoreactive hilar cells. Similarly, there was no difference between the number of PV-immunoreactive cells 1 month after injury in the granule cell layer $(95.2 \pm 12.4 \%$ of control), compared with either control or the 1-week injury group (see above). Also, the decreases in the CCK-immunoreactive cells in the hilus showed no change between 1 week and 1 month postinjury time points [ 1 month after injury ( $n=5$ animals): $57.4 \pm 6.7 \%$, compared with $55.7 \pm 5.6 \% 1$ week after impact].

\section{The decrease in the number of PV- and CCK-positive hilar cells is similar to the decrease in the number of GluR2/3-positive hilar mossy cells}

The close similarity between the percentage decreases in the PVand CCK-immunoreactive hilar cell populations was surprising, because these two interneuronal groups are nonoverlapping, and recent results indicate that they may also have different target specificities (e.g., the hilar axon collaterals of CCK-positive basket cells may exclusively target mossy cells) (Leranth and Frotscher, 1986; Freund and Buzsáki, 1996; L. Acsády, personal communication). The average loss of hilar cells, as determined from Nissl stains $(58.7 \pm 1.8 \%)$, was certainly comparable to the percentage decrease in the number of PV- $(67.1 \pm 4.6 \%)$ and CCK-positive $(55.7 \pm 5.6 \%)$ hilar neurons (Fig. $4 B)$. To compare the decrease in the number of the PV-and CCK-immunoreactive cells with the cell population that is considered to be among the most vulnerable in the entire brain, the hilar mossy cells, we performed additional immunocytochemical experiments using an antibody raised against GluR2/3, which labels hilar mossy cells but not hilar GABAergic neurons (Leranth et al., 1996). Although there was a considerable decrease in the number of GluR2/3 immunoreactive cells 1 week after injury (Fig. 5), the percentage decrease (64.6 \pm $4.1 \%$ ) was not statistically different from the values reported above for either the PV- or CCK-positive hilar cells (Fig. 4B) (note that for each animal for all the immunocytochemical experiments, the hilar cell loss, verified from Nissl-stained sections, was not statistically different). Indeed, the percentage decrease in the number of GluR2/3-positive hilar cells was similar to the average decrease in hilar cell number, as determined from Nisslstained sections (Fig. $4 B$ ); the decrease in the number of GluR2/3 immunoreactive hilar cells 1 month after injury $(n=3$ animals; $56.6 \pm 2.6 \%$ decrease) was similar to the decrease observed 1 week after impact. These data led us to formulate the hypothesis (which we will refer to as the "pressure wave" hypothesis) that the mechanical pressure wave, unlike any other forms of insult, may impact most hilar cells in a similar manner, via the physical stretching and bending of the processes of these neurons, which are large and not tightly packed in a cell layer.

\section{Mechanical pressure wave-induced immediate injury to neurons in the dentate gyrus}

If the above "pressure wave" hypothesis were true, one would expect that the pressure wave-induced damage would be immediate; i.e., if the similar perturbations observed in the PV, CCK, and GluR2/3 neuronal populations in the hilus were attributable to the physical stretching and bending of the neuronal processes, the injury would take place during the pressure transient triggered by the impact; by contrast, injury attributable to some "biological" process, e.g., by the impact-induced increase in glutamate release, etc., would require some time after the impact. It was not feasible to test this hypothesis using either electrophysiological or immunocytochemical methods; e.g., it takes time to cut slices and establish whole-cell recordings, and protein levels in the injured cells are unlikely to change in an immediate manner after the passing through of the pressure wave. However, the Gallyas silver stain (Gallyas et al., 1990, 1992a,b,c; van den Pol and Gallyas, 1990) can be used to detect injury to neuronal processes that occur quickly after the insult. The principle of the stain is thought to be related to neuronal polymeric cytoskeletal elements breaking during the insult, exposing charges from the monomers that may trigger the process of silver accumulation, in a manner reminiscent of the intensification process during photography (Gallyas et al., 1992c); obviously, although this silver stain is ideal for the identification of injured or stressed neurons in a rapid manner, it is not designed to determine whether the labeled neuron will or will not survive the initial injury (see below). Indeed, this method has been shown to reveal injured 

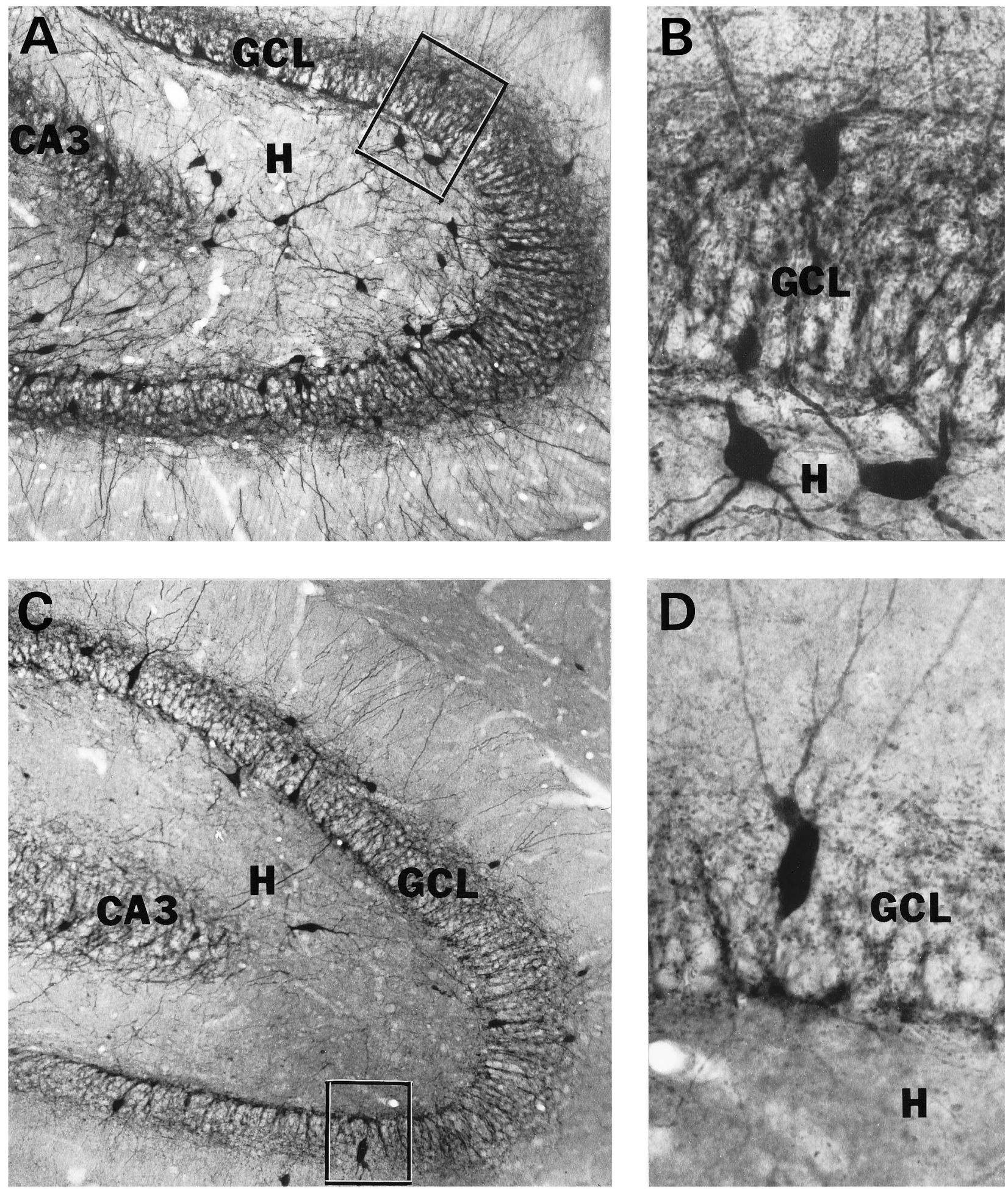

Figure 3. The number of PV-immunostained neurons in the hilus and the density of PV-positive fibers in the hilus and in the granule cell layer are decreased after head injury. $A, B, \mathrm{PV}$ immunostaining in age-matched, sham-operated control. Note the presence of PV-positive cells and processes in the hilus and in and above the granule cell layer. The area outlined in $A$ is shown at higher magnification in $B$. $C, D$, One week after head injury, the hilus contains fewer PV-positive cells and processes. Similarly, there is a considerable decrease in the density of PV-positive fibers in and above the granule cell layer (e.g., compare $B$ and $D$ ). However, despite the great decrease in the number of hilar PV-positive cells, numerous PV-immunostained neurons can be observed in the granule cell layer. The area outlined in $C$ is shown at higher magnification in $D$. Magnifications: $A, C, 112 \times ; B, D, 500 \times$. $H$, Hilus; $G C L$, granule cell layer. 

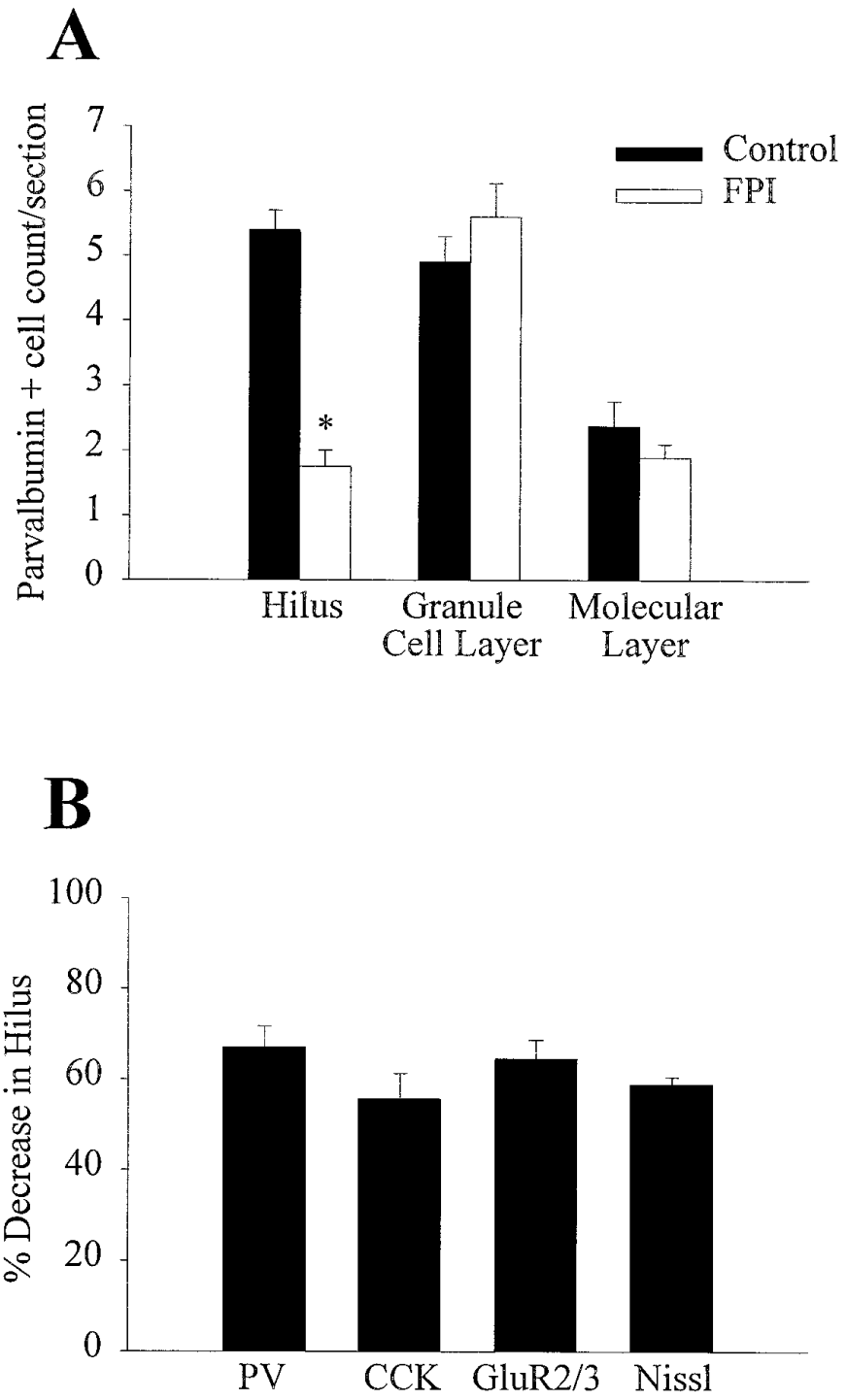

Figure 4. Head injury-induced alterations in the interneuronal circuitry of the dentate gyrus. $A$, Fluid percussion injury causes a significant decrease in the number of parvalbumin $(P V)$-immunostained cells in the hilus, without a change in the number of PV-positive cells in the granule cell and molecular layers, 1 week after impact, compared with agematched, sham-operated controls. $B$, Percentage decrease in the number of PV-, CCK-, and GluR2/3-positive cells in the hilus of the dentate gyrus (in each case, with respect to age-matched, sham-operated controls). Note that the post-traumatic percentage decrease in the number of PV- and CCK-positive cells in the hilus is similar to the decrease in the number of GluR2/3-immunostained mossy cells (one of the most injury-sensitive cell types in the entire brain in various models of epilepsy and ischemia), as well as to the average decrease in the total number of hilar cells (as determined from Nissl-stained sections).

neurons immediately after direct physical damage to neurons (van den Pol and Gallyas, 1990; Gallyas et al., 1992a). Therefore, we used the Gallyas silver stain to determine whether the hilar cells are injured in an immediate manner after fluid percussion head trauma and whether the immediate injury is selective to hilar neurons compared with the granule cells, which are smaller and tightly packed in a cell layer. As illustrated in Figure $6 A, C$, numerous hilar cells appeared darkly stained when the animals $(n=3)$ were fixed immediately after the impact (it took 50-60 sec to quickly open the thoracic cavity and begin the transcardial
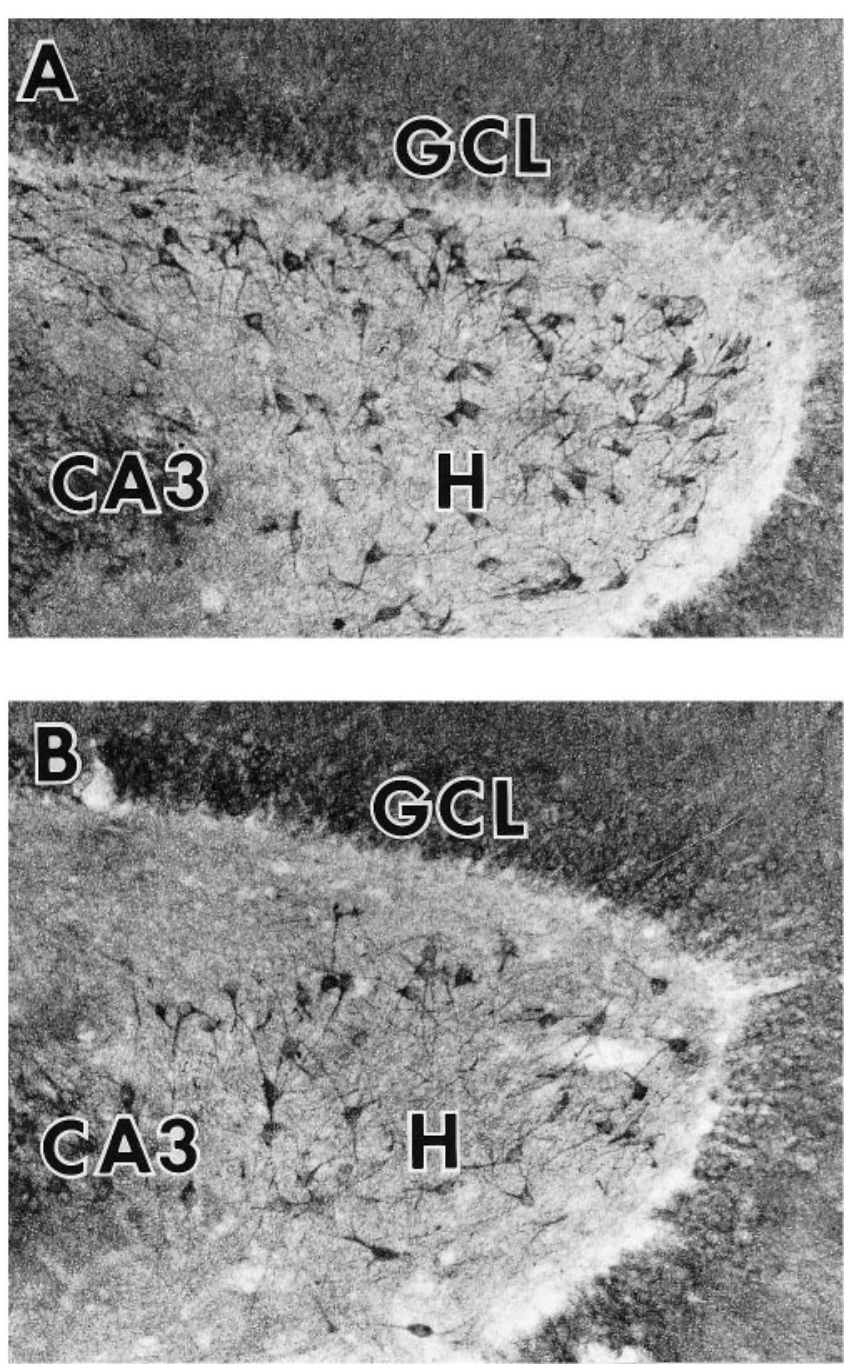

Figure 5. Decrease in the number of the GluR2/3-immunoreactive mossy hilar cells after fluid percussion injury. $A$, GluR $2 / 3$ immunostaining shows numerous mossy cells (Leranth et al., 1996) in the hilus of the dentate gyrus of an age-matched, sham-operated control animal. $B$, The number of GluR2/3-immunostained cells in the hilus is decreased 1 week after head injury. Magnification: $90 \times . H$, Hilus; $G C L$, granule cell layer.

administration of the fixative after the delivery of the fluid percussion injury). By contrast, granule cells in the dentate gyrus appeared to be unstained (Fig. 6A,C). Similarly, control animals $(n=3)$ (Fig. $6 B)$ showed no darkly stained neurons in the hilus. Unexpectedly, although dentate granule cells appeared to be unstained, large, pyramidal-shaped basket-like cells in the granule cell layer were revealed by the silver stain (Figs. 6C,D), presumably because large cells may be more susceptible to the direct mechanical pressure wave-induced injury, even if they are in cell layers in which they are surrounded by small, tightly packed cells such as the dentate granule cells. Although these results were compatible with the "pressure wave" hypothesis, a concern remained that during the $\sim 1$ min delay between the impact and the beginning of the administration of the fixative, there could be some physiological process that may have contributed to the neuronal damage. Therefore, we took advantage of the fact that the Gallyas stain does not require the presence of living cells to reveal physical damage (van den Pol and Gallyas, 1990; Gallyas et al., 1992b,c), and we performed fluid percussion injury on animals 

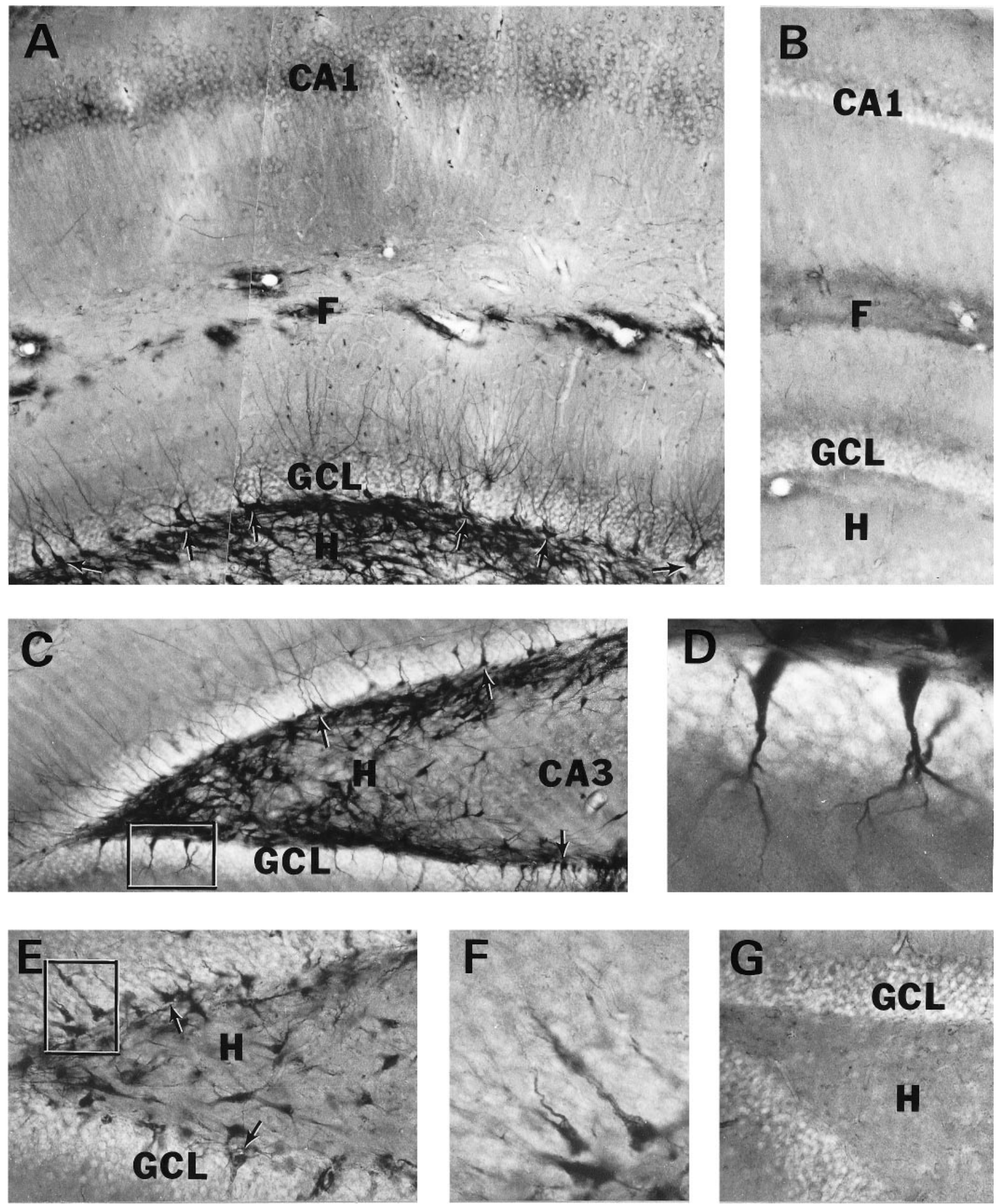

Figure 6. The trauma-induced perturbation of the dentate interneuronal network is immediate and does not require the recruitment of active physiological processes. $A, C$, Silver staining in an animal that was transcardially fixed immediately after fluid percussion injury. Note the presence of numerous darkly stained cells in the dentate hilus and also a subset of the darkly stained cells (interneurons, see below) in the granule cell layer. Note the lack of staining of CA1 neurons (in $A$ ) and granule cells (e.g., in $C$ ). $B$, Sections from age-matched, sham-operated control animals remained unstained. $C, D$, The cells that appeared darkly stained in the granule cell layer after fluid percussion injury had large and most often pyramidal-shaped somata, indicating that these cells were basket cells. $E, F$, The pattern of silver-stained cells in the hilus and the granule cell layer was essentially unchanged when fluid percussion injury was performed in animals that were prefixed with a fixative solution, indicating that the initial mechanical injury to dentate interneurons does not require the active recruitment of physiological processes. Magnifications: $A-C, 125 \times ; D, 500 \times ; E, F, 190 \times ; F, 430 \times$. $H$, Hilus; $G C L$, granule cell layer; $F$, fissure. 
$(n=3)$ that were fixed via transcardial administration of the fixative before impact. As shown in Figure $6 E, F$, even in these prefixed animals, hilar cells and the large, basket-like cells in the granule cell layer appeared darkly silver-stained, whereas the granule cells remained unstained. Similarly, in control animals we found no darkly stained hilar cells or large basket-like cells in the granule cell layer $(n=3)$ (Fig. $6 G)$. To further reduce the probability that some biological event contributed to the observed injury pattern, these latter experiments were also repeated in animals $(n=3)$ that were prefixed with chilled $\left(4-8^{\circ} \mathrm{C}\right)$ fixative containing in addition to glutaraldehyde the broad-spectrum glutamate receptor blocker kynurenate $(1 \mathrm{~mm})$. Before the administration of this fixative, the animals were also perfused for $5 \mathrm{~min}$ with a chilled saline solution containing kynurenate. Similar to the nonfixed and prefixed cases, the animals that were prefixed with a chilled fixative containing kynurenate still showed specific labeling in the hilus and of the large cells in the granule cell layer (not shown), whereas the granule cells themselves appeared unstained. These results, together with those of the immunocytochemical experiments, suggest that the purely physical stretching, compressing, and bending action of the mechanical pressure wave on the large dentate neurons during impact is likely to be an important factor in determining the pattern of neuronal disturbance that is manifested in the post-traumatic development of hyperexcitability.

\section{Modification of the initial, "physical" injury pattern at later time points}

The presence of darkly silver-stained, large, pyramidal-shaped basket-like cells in the granule cell layer after fluid percussion injury suggested that the initial impact, most likely caused by the physical stresses exerted on the neuronal profiles by the pressure wave, may be subsequently modified by other factors, because the number of PV- and CCK-positive cells that were situated in the granule cell layer did not change 1 week after injury (see above). However, although the PV- and CCK-positive interneurons together provide all the known perisomatic GABAergic input to the dentate granule cells, they constitute only $\sim 70 \%$ of the total nongranule cell population residing within the granule cell layer (Freund and Buzsáki, 1996). Therefore, the possibility remained that the silver stain revealed immediate injury exclusively to the non-PV and non-CCK-positive basket cells in the granule cell layer, which may disappear after the fluid percussion injury. A recent study (Acsády et al., 1997) has shown that immunostaining using an antibody raised against the SPR constitutes a specific marker for virtually all basket cell populations in the granule cell layer, including the PV-, CCK-, vasoactive intestinal polypeptide-, and neuropeptide-Y-positive cells. Because several dentate interneurons, including basket cells, are long-range projection cells, GABA or glutamic acid decarboxylase (GAD) immunocytochemistry cannot be used for these experiments, because of the low and variable levels of GABA and GAD immunoreactivity present in GABAergic cells with distant projections. Colchicine injections can enhance the staining, but the interpretation of any quantitative data obtained from the colchicine-treated animals would be difficult (Ribak et al., 1986; Miettinen et al., 1992; Tóth et al., 1993; Freund and Buzsáki, 1996). Therefore, we used the SPR antibody (courtesy of Dr. Shigemoto) to ascertain the posttraumatic status of the non-PV-and non-CCK-positive interneurons in the granule cell layer. As reported before (Acsády et al., 1997) and as shown in Figure $7 A$, SPR immunocytochemistry reveals a dense pattern of a darkly stained meshwork of cells and
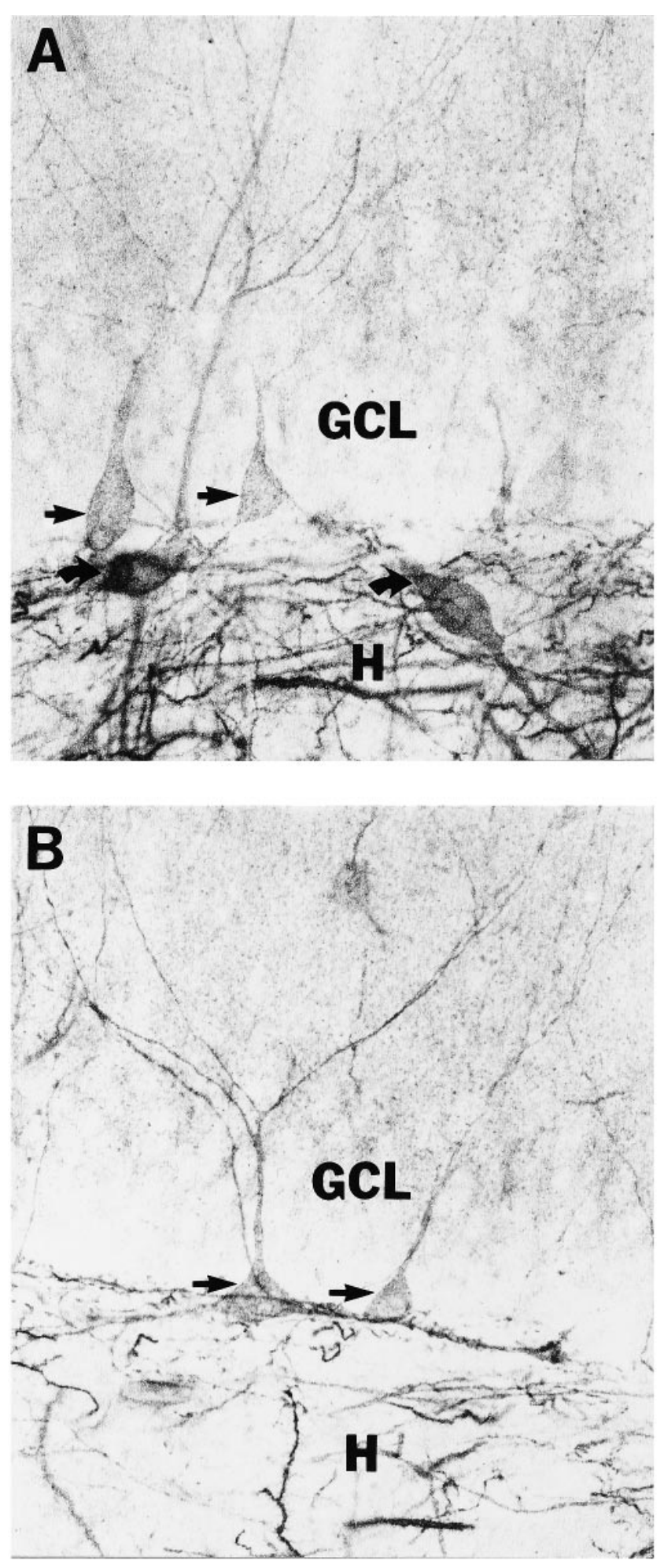

Figure 7. SPR immunostaining is severely decreased in the hilus, but the number of SPR-immunostained cells remains unchanged in the granule cell layer. $A$, SPR immunostaining shows a dense meshwork of GABAergic cells (curved arrows) and processes (Acsády et al., 1997) in the dentate hilus in a section from an age-matched, sham-operated control, and the presence of pyramidal-shaped cells (straight arrows) in the granule cell layer. $B$, After fluid percussion injury, the density of SPR-positive cells and processes is greatly decreased in the hilus, indicating a disturbance of the GABAergic hilar network. However, the pyramidal-shaped interneurons can still be observed in the granule cell layer (arrows). Magnification: $450 \times$. $H$, Hilus; $G C L$, granule cell layer. 
dendrites in the hilus that belongs to GABAergic neurons. There was a prominent reduction of the SPR-positive profiles in the hilus 1 month after injury ( $n=3$ animals) (Fig. $7 B)$ compared with age-matched, sham-operated controls (Fig. 7A). Quantification of the changes in SPR-positive hilar cells was made difficult by the fact that the staining in control slices is very dense in the hilus, because this antibody reveals the dendritic and somatic processes of several subclasses of hilar GABAergic neurons (Acsády et al., 1997). The reduction of the SPR-staining in the hilus after fluid percussion injury, together with the reduction in the number of various markers for hilar GABAergic cells [see above; also, there is a reduction of somatostatin-positive hilar cells after fluid percussion injury (Lowenstein et al., 1992)], further suggested that a long-lasting disturbance of the GABAergic hilar interneuronal network takes place after head injury. Unlike the SPR-immunostained cell bodies in the hilus, it was possible to quantify the number of SPR-positive cells that were situated in the granule cell layer. These experiments revealed that 1 month after fluid percussion injury, the SPR-positive cells in the granule cell layer appeared largely unchanged $(91.16 \pm 4.5 \%$ of control; $n=3$ ). These results suggest that most of the large, pyramidalshaped basket-like cells in the granule cell layer, observed in the Gallyas-stained material immediately after head injury, survive the initial injury. Therefore, the initial "physical" injury pattern is modified at later time points, most likely by biological factors (e.g., the density of mossy fiber innervation, postsynaptic glutamate receptors, the capacity to effectively buffer intracellular calcium rises, and the loss of target structures).

\section{DISCUSSION}

The main findings of this paper are that (1) the feed-forward inhibitory control of granule cell discharges, the frequency of mIPSCs, and the density of PV-positive fibers in the granule cell layer are decreased after head injury; (2) the amplitude and kinetics of mIPSCs in granule cells are not changed after trauma; (3) trauma affects the PV- and CCK-positive hilar cell populations more than those that reside in the granule cell layers; (4) injury to the hilar neurons takes place instantaneously after the impact; and (5) the initial physical stress does not require the recruitment of active physiological processes.

\section{Traumatic injury to the feed-forward, perisomatic inhibitory control of dentate granule cells}

The association between head trauma and the development of temporal lobe epilepsy is well established (Jennet, 1975). Hilar neurons are selectively vulnerable to head trauma, a fact that has been suggested to be causally linked to limbic hyperexcitability (Lowenstein et al., 1992). In particular, the perisomatic inhibitory control of dentate granule cells is likely to be crucial in regulating the gating function of the dentate gyrus in the post-traumatic entorhinohippocampal system. Therefore, although the data presented in this paper, together with previous results (Lowenstein et al., 1992), demonstrate that a single, moderate mechanical pressure wave, delivered epidurally at a relatively remote location, impacts virtually the entire hilar interneuronal network, the pattern of damage to the dentate basket and axo-axonic cells is likely to be especially significant for the ability of the dentate gyrus to effectively regulate the spread of excitability from the entorhinal cortex to the hippocampus. Basket and axo-axonic cells are in a strategically unique position within the network to regulate the transmission of activity from the entorhinal cortex to the rest of the hippocampal formation, because (1) these cells receive direct entorhinal input onto their dendrites in the molecular layer, (2) they are fast-spiking interneurons with an extremely low threshold for entorhinal activation, and (3) they release GABA precisely onto those regions of granule cells that are the most crucial for action potential generation, i.e., the perisomatic region, including the axon initial segment (Buzsáki et al., 1983; Halasy and Somogyi, 1993; Kneisler and Dingledine, 1995; Soltesz, 1995; Deller et al., 1996; Freund and Buzsáki, 1996). By contrast, somatostatin-positive hilar cells, another important GABAergic cell population known to be affected by the pressure wave-transient (Lowenstein et al., 1992), do not have dendrites in the molecular layer, and their axons innervate the most distal dendritic regions of granule cells (i.e., these cells do not take part in the feed-forward control of granule cells; however, via their mossy fiber inputs, they play an important role in feedback regulation of dendritic excitability) (Freund and Buzsáki, 1996).

\section{Patterns of immediate damage to hippocampal neuronal networks in head trauma}

A major finding in this paper is that the pressure wave causes physical damage to hilar cells and to those pyramidal-shaped basket cells that are located in the granule cell layer in an immediate manner, and that this injury does not require the recruitment of active physiological processes (because the same pattern of damage is evoked in cooled, fixed animals loaded with glutamate receptor antagonists). Importantly, the data demonstrate that the pattern of physical injury is selective (e.g., hilar cells but not the neighboring granule cells are affected) even after fixation, indicating that the mechanical pressure wave preferentially impacts large cells and/or cells that are not tightly packed in a cell layer. Smaller cells with less extensive processes are likely to be subjected to smaller pressure differences (i.e., stretching and bending) during the passage of the pressure wave-transient (the preferential sensitivity of large, unsupported objects to breakage from traveling pressure waves is well known in seismology, e.g., Bolt, 1993; smaller objects can simply rise and fall during the waves without sustaining extensive stretching and bending). This principle may explain the initial injury to hilar cells and to large neurons located in the granule cell layer, whereas the small, tightly packed granule cells may suffer relatively little physical stress during the pressure pulse. Differences in cytoskeletal structures may also contribute to the pattern of damage after impact. Although this paper concentrated on the dentate gyrus, it is interesting to note that some of the relatively loosely packed CA3c cells were occasionally observed to be darkly stained by the Gallyas method after impact [indeed, CA3c cells may suffer some small degree of cell loss in fluid percussion injury (Coulter et al., 1996)], and some large cells with extensive dendritic arbors were also silver-stained in the lacunosum-moleculare of CA1 region. By contrast, CA1 pyramidal cells did not appear to be damaged by the pressure wave, indicating that large cells tightly packed in a cell layer with other cells of similar size (i.e., unlike the basket cells in the granule cell layer; the similar size is likely to help to evenly distribute the physical strain during the passage of the pressure wave) are relatively resistant to this type of mechanical insult.

\section{Location-specific vulnerability of basket and axo-axonic cells}

The perisomatic inhibitory input to dentate granule cells arises from the nonoverlapping populations of PV- or CCK-positive 
interneurons. Interestingly, data in this paper indicate that both of these nonoverlapping interneuronal populations showed preferential injury (as seen by the decrease in the number of PV-and CCK-positive cell bodies) when their somata were located in the hilus, although basket cell-like neurons in the granule cell layer also appeared to be affected by the initial impact. The reason for this location-specific injury sensitivity is not known at present. It is possible that interneurons located in the dentate hilus receive a more significant mossy fiber input than those in the granule cell layer, which may induce larger excitotoxic damage [significantly, both the NMDA and the AMPA receptors expressed in dentate basket cells are highly $\mathrm{Ca}^{2+}$-permeable (Koh et al., 1995)]. A similar difference between the injury sensitivity of the PVpositive cells in the hilus versus those in the granule cell layer has been reported after sustained stimulation of the perforant path, and after pilocarpine-induced seizures as well (Sloviter, 1991; Obenaus et al., 1993). Therefore, it will be of great interest in future studies to determine whether location-specific physiological differences exist between the basket and axo-axonic cells in the dentate gyrus. It should also be pointed out that the tightly packed granule cell layer may offer some degree of physical protection against the traveling wave to large cells within the layer, i.e., although basket cell-like neurons were labeled by the silver stain in the granule cell layer immediately after impact, these cells may have suffered less stretching and bending than their counterparts that resided in the hilus. In any case, the differential post-traumatic decrease in the number of PV- and CCK-positive cells in the hilus versus the granule cell layer is likely to be a fundamentally important feature of the posttraumatic corticolimbic system.

\section{Implications for post-traumatic epilepsy}

Two million people suffer traumatic brain injury in the United States annually, and brain trauma is the leading cause of death and disability among young adults (Grahm et al., 1990; Harrison and Dijkers, 1992; LeRoux and Grady, 1995). Of head trauma survivors, 10-15\% develop post-traumatic epilepsy, and after penetrating injuries this number rises to $53 \%$ (Salazar et al., 1985; Salazar, 1992). Indeed, head injury is an important contributing etiology of remote symptomatic epilepsy (Annegers et al., 1980). Post-traumatic epilepsies (most often complex partial seizures) are frequently accompanied by neuropathological changes in the limbic cortex and the temporal lobe (Gualtieri and Cox, 1991); furthermore, head trauma frequently leads to disturbances of memory, which may also be related to perturbations within hippocampal circuits (Binder, 1986; Rempel-Clower et al., 1996). The fluid percussion model has been rapidly gaining popularity, because it replicates various histological, behavioral, and cognitive consequences of concussive trauma (Lowenstein et al., 1992). Although the incidence of epilepsy is higher after penetrating head injuries compared with concussive, closed head injuries, pressure waves are major factors in several types of penetrating head injuries as well; e.g., when a high-speed bullet enters the head, it generates shock waves spreading in front of the bullet, resulting in damage remote from the missile tract (Leroux and Winn, 1995). In vitro kindling experiments showed that fluid percussion-injured slices generate self-sustaining epileptiform activity with a lowered threshold compared with controls, and the site of enhanced epileptogenesis was located primarily in the dentate gyrus, not in CA1 (Coulter et al., 1996). The CA1 region seems to be relatively resistant to the immediate effects of the pressure wave, and the most prominent post-traumatic cell loss occurs in the hilus (Lowenstein et al., 1992; Coulter et al., 1996). The results presented here demonstrate for the first time that the perisomatic inhibitory system of the dentate gyrus is perturbed after head trauma. The findings indicate that a substantial portion of the dentate interneuronal network, especially those interneurons that reside in the granule cell layer, seem to preferentially recover from the initial shock wave-induced injury. Therefore, future efforts to enhance post-traumatic resistance against hyperexcitability and increase functional recovery may target these interneurons.

\section{REFERENCES}

Acsády L, Katona I, Gulyas AI, Shigemoto R, Freund TF (1997) Immunostaining for substance P receptor labels GABAergic cells with distinct termination patterns in the hippocampus. J Comp Neurol 378:320-336.

Amaral DG (1978) A Golgi study of cell types in the hilar region of the hippocampus in the rat. J Comp Neurol 182:851-914.

Annegers JF, Grabow JD, Groover RV, Laws Jr ER, Eiveback LR, Kurkland LT (1980) Seizures after head trauma: a population study. Neurology 30:683-689.

Baimbridge KG, Miller JJ (1982) Immunohistochemical localization of calcium-binding protein in the cerebellum, hippocampal formation and olfactory bulb of the rat. Brain Res 245:223-229.

Binder LM (1986) Persisting symptoms after mild head injury: a review of the postconcussive syndrome. J Clin Exp Neuropsychol 8:323-346.

Blanton MG, LoTurco JJ, Kriegstein AR (1989) Whole cell recording from neurons in slices of reptilian and mammalian cerebral cortex. J Neurosci Methods 30:203-210.

Bolt B (1993) Earthquakes. New York: W. H. Freeman.

Bruton C (1988) The neuropathology of temporal lobe epilepsy. New York: Oxford UP.

Buckmaster PS, Schwartzkroin PA (1995) Interneurons and inhibition in the dentate gyrus of the rat in vivo. J Neurosci 15:774-789.

Buckmaster PS, Tam E, Schwartzkroin PA (1996) Electrophysiological correlates of seizure sensitivity in the dentate gyrus of epileptic juvenile and adult gerbils. J Neurophysiol 76:2169-2180.

Buhl EH, Han ZS, Lorinczi Z, Stezhka VV, Karnup SV, Somogyi P (1994) Physiological properties of anatomically identified axo-axonic cells in the rat hippocampus. J Neurophysiol 71:1289-1307.

Buhl EH, Cobb SR, Halasy K, Somogyi P (1995) Properties of unitary IPSPs evoked by anatomically identified basket cells in the rat hippocampus. Eur J Neurosci 7:1989-2004.

Buzsáki G, Leung LW, Vanderwolf CH (1983) Cellular bases of hippocampal EEG in the behaving rat. Brain Res 287:139-171.

Cortez SC, McIntosh TK, Noble LJ (1989) Experimental fluid percussion brain injury: vascular disruption and neuronal and glial alterations. Brain Res 482:271-282.

Coulter DA, Rafiq A, Shumate M, Gong QZ, DeLorenzo RJ, Lyeth BG (1996) Brain injury-induced enhanced limbic epileptogenesis: anatomical and physiological parallels to an animal model of temporal lobe epilepsy. Epilepsy Res 6:81-91.

Deller T, Martinez A, Nitsch R, Frotscher M (1996) A novel entorhinal projection to the rat dentate gyrus: direct innervation of proximal dendrites and cell bodies of granule cells and GABAergic neurons. J Neurosci 16:3322-3333.

Dixon CE, Lyeth BG, Povlishock JT, Findling RL, Hamm RJ, Marmarou A, Young HF, Hayes RL (1989) A fluid percussion model of experimental brain injury in the rat. J Neurosurg 67:110-119.

Freund TF, Buzsáki G (1996) Interneurons of the hippocampus. Hippocampus $6: 345-470$.

Gallyas F, Guldner FH, Zoltay G, Wolff JR (1990) Golgi-like demonstration of "dark" neurons with an argyrophil III method for experimental neuropathology. Acta Neuropathol (Berl) 79:620-628.

Gallyas F, Zoltay G, Balas I (1992a) An immediate light microscopic response of neuronal somata, dendrites and axons to contusing concussive head injury in the rat. Acta Neuropathol (Berl) 83:394-401.

Gallyas F, Zoltay G, Horvath Z (1992b) Light microscopic response of neuronal somata, dendrites and axons to post-mortem concussive head injury. Acta Neuropathol (Berl) 83:499-503.

Gallyas F, Zoltay G, Dames W (1992c) Formation of "dark" (argyrophilic) neurons of various origin proceeds with a common mechanism 
of Biophysical nature (a novel hypothesis). Acta Neuropathol (Berl) 83:504-509.

Grahm TW, Williams Jr FC, Harrington T, Spetzler RF (1990) Civilian gunshot wounds to the head: a prospective study. Neurosurgery 27:696-700.

Gualtieri T, Cox DR (1991) The delayed neurobehavioural sequelae of traumatic brain injury. Brain Injury 5:219-232.

Gulyas AI, Gorcs TJ, Freund TF (1990) Innervation of different peptidecontaining neurons in the hippocampus by GABAergic septal afferents. Neuroscience 37:31-44.

Halasy K, Somogyi P (1993) Subdivisions in the multiple GABAergic innervation of granule cells in the dentate gyrus of the rat hippocampus. Eur J Neurosci 5:411-429.

Han ZS, Buhl EH, Lorinczi Z, Somogyi P (1993) A high degree of spatial selectivity in the axonal and dendritic domains of physiologically identified local-circuit neurons in the dentate gyrus of the rat hippocampus. Eur J Neurosci 5:395-410.

Harrison CL, Dijkers M (1992) Traumatic brain injury registries in the United States: an overview. Brain Injury 6:203-212.

Hollrigel GS, Toth K, Soltesz I (1996) Neuroprotection by propofol in acute mechanical injury: role of GABAergic inhibition. J Neurophysiol 76:2412-2422.

Hollrigel GS, Soltesz I (1997) Slow kinetics of miniature IPSCs during early postnatal development in granule cells of the dentate gyrus. J Neurosci 17:5119-5128.

Jennet B (1975) Epilepsy after non-missile head injuries. London: Heinemann.

Kneisler TB, Dingledine R (1995) Spontaneous and synaptic input from granule cells and the perforant path to dentate basket cells in the rat hippocampus. Hippocampus 5:151-164.

Koh DS, Geiger JR, Jonas P, Sakmann B (1995) Ca(2+)-permeable AMPA and NMDA receptor channels in basket cells of rat hippocampal dentate gyrus. J Physiol (Lond) 485:383-402.

Leranth C, Frotscher M (1986) Synaptic connections of cholecystokininimmunoreactive neurons and terminals in the rat fascia dentata: a combined light and electron microscopic study. J Comp Neurol 254:51-64.

Leranth C, Szeidemann Z, Hsu M, Buzsáki G (1996) AMPA receptors in the rat and primate hippocampus: a possible absence of GluR2/3 subunits in most interneurons. Neuroscience 70:631-652.

LeRoux PD, Grady MS (1995) Epidemiology of head injury. In: Anesthetic management of head injury (Lam AM, ed), pp 1-11. New York: McGraw-Hill.

LeRoux PD, Winn HR (1995) Surgical management of acute head injury. In: Anesthetic management of head injury (Lam AM, ed), pp 101-141. New York: McGraw-Hill.

Lowenstein DH, Thomas MJ, Smith DH, McIntosh TK (1992) Selective vulnerability of dentate hilar neurons following traumatic brain injury: a potential mechanistic link between head trauma and disorders of the hippocampus. J Neurosci 12:4846-4853.

Lyeth BG, Dixon CE, Jenkins LW, Hamm RJ, Alberico A, Young HF, Stonnington HH, Hayes RL (1988) Effects of scopolamine treatment on long-term behavioral deficits following concussive brain injury to the rat. Brain Res 452:39-48.

Margerison JH, Corsellis JA (1966) Epilepsy and the temporal lobes. A clinical, electroencephalographic and neuropathological study of the brain in epilepsy, with particular reference to the temporal lobes. Brain 89:499-530.

McIntosh TK, Vink R, Noble L, Yamakami I, Fernyak S, Soares H, Faden AL (1989) Traumatic brain injury in the rat: characterization of a lateral fluid-percussion model. Neuroscience 28:233-244.

Miettinen R, Gulyas AI, Baimbridge KG, Jacobowitz DM, Freund TF (1992) Calretinin is present in non-pyramidal cells of the rat hippocampus-II. Co-existence with other calcium binding proteins and GABA. Neuroscience 48:29-43.
Miles R, Toth K, Gulyas AI, Hajos N, Freund TF (1996) Differences between somatic and dendritic inhibition in the hippocampus. Neuron 16:815-823.

Obenaus A, Esclapez M, Houser CR (1993) Loss of glutamate decarboxylase mRNA-containing neurons in the rat dentate gyrus following pilocarpine-induced seizures. J Neurosci 13:4470-4485.

Otis TS, Mody I (1992) Modulation of decay kinetics and frequency of $\mathrm{GABA}_{\mathrm{A}}$ receptor-mediated spontaneous inhibitory postsynaptic currents in hippocampal neurons. Neuroscience 49:13-32.

Povlishock JT, Hayes RL, Michel ME, McIntosh TK (1994) Workshop on animal models of traumatic brain injury. J Neurotrauma 11:723-732.

Prasad MR, Dhillon HS, Carbary T, Dempsey RJ, Scheff SW (1994) Enhanced phosphodiestric breakdown of phosphatidylinositol bisphosphate after experimental brain injury. J Neurochemistry 63:773-776.

Rempel-Clower NL, Zola SM, Squire LR, Amaral DG (1996) Three cases of enduring memory impairment after bilateral damage limited to the hippocampal formation. J Neurosci 16:5233-5255.

Ribak CE, Seress L, Peterson GM, Seroogy KB, Fallon JH, Schmued LC (1986) A GABAergic inhibitory component within the hippocampal commissural pathway. J Neurosci 6:3492-3498.

Salazar AM (1992) Traumatic brain injury: the continuing epidemic. In: Challenges in neurology (Hachinski VC, ed), pp 55-67. Philadelphia, PA: Davis.

Salazar AM, Jabbari B, Vance SC, Grafman J, Amin D, Dillon JD (1985) Epilepsy after penetrating head injury. I. Clinical correlates: a report of the Vietnam Head Injury Study. Neurology 35:1406-1414.

Schumate M, Azhar R, Lyeth B, Gong Q-Z, Coulter D (1995) Traumatic brain injury produces loss of neurons in the hilus and CA3 but no significant mossy fiber sprouting in the hippocampus. Epilepsia 36[Suppl 4]:118.

Shigemoto R, Nakaya Y, Nomura S, Ogawa-Meguro R, Ohishi H, Kaneko T, Nakanishi S, Mizuno N (1993) Immunocytochemical localization of rat substance P receptor in the striatum. Neurosci Lett 153:157-160.

Sloviter RS (1991) Permanently altered hippocampal structure, excitability, and inhibition after experimental status epilepticus in the rat: the "dormant basket cell" hypothesis and its possible relevance to temporal lobe epilepsy. Hippocampus 1:41-66.

Soltesz I (1995) A brief history of cortico-hippocampal time with special reference to the direct entorhinal input to CA1. Hippocampus 5:120-125.

Soltesz I, Mody I (1994) Patch-clamp recordings reveal powerful GABAergic inhibition in dentate hilar neurons. J Neurosci 14:2365-2376.

Soltesz I, Mody I (1995) Ca2+-dependent plasticity of miniature inhibitory postsynaptic currents after amputation of dendrites in central neurons. J Neurophysiol 73:1763-1773.

Soltesz I, Smetters DK, Mody I (1995) Tonic inhibition originates from synapses close to the soma. Neuron 14:1273-1283.

Soriano E, Nitsch R, Frotscher M (1990) Axo-axonic chandelier cells in the rat fascia dentata: Golgi-electron microscopy and immunocytochemical studies. J Comp Neurol 293:1-25.

Staley KJ, Otis TS, Mody I (1992) Membrane properties of dentate gyrus granule cells: comparison of sharp microelectrode and whole-cell recordings. J Neurophysiol 67:1346-1358.

Toth K, Borhegyi Z, Freund TF (1993) Postsynaptic targets of GABAergic hippocampal neurons in the medial septum-diagonal band of broca complex. J Neurosci 13:3712-3724.

Traub RD, Miles R (1991) Neuronal networks of the hippocampus. Cambridge: Cambridge UP.

van den Pol AN, Gallyas F (1990) Trauma-induced Golgi-like staining of neurons: a new approach to neuronal organization and response to injury. J Comp Neurol 296:654-673.

West MJ, Slomianka L, Gundersen HJ (1991) Unbiased stereological estimation of the total number of neurons in the subdivisions of the rat hippocampus using the optical fractionator. Anat Rec 231:482-497. 